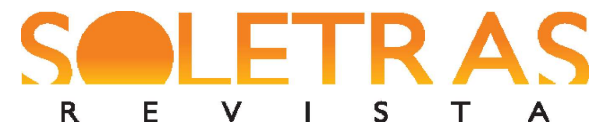

DOSSIÊ-N. 35 - 2018.1 - ANNA COSTANTINO

ASSIA SLIMANI-ROLLS

\title{
Practitioner research and the challenges of the good teaching canon in multilingual and multicultural globalized society
}

\author{
Anna Costantino ${ }^{1}$ \\ Assia Slimani-Rolls ${ }^{2}$
}

\begin{abstract}
This article seeks to respond to some of the tensions that face language teacher educators in globalized society. For teachers, an increasingly diverse, multicultural and multilingual globalized world means having to acknowledge diversity in their daily pedagogy, while confronting inequality in the distribution of learning resources and the demands of ever- bureaucratized educational settings. Even when theory indicates spaces for the enactment of local pedagogies responding to those challenges, teachers are unable to translate academic-based research into practice. This article argues for practitioner enquiry, practiced by the authors as Exploratory Practice (ALLWRIGHT, HANKS, 2009; HANKS, 2015a; SLIMANI-ROLLS, KIELY, 2014), as an instance of how the empowering spaces suggested by theory can indeed be enacted as lived educational experience.
\end{abstract}

Keywords: Exploratory practice. Language teacher education. Practitioner research. Globalization.

\section{Introduction}

Language teacher professionalism is today the crucible of a number of tensions that have been brought about by the very multifaceted nature of globalization processes and demands on education. One amongst the many challenges facing (language) educators in times of rapid changes is having to navigate increasing diversity in multilingual, multiethnic and multicultural educational environments, while seeking to grasp the opportunities afforded by globalized society. As Cochran-Smith and Villegas (2015) suggest in their review of literature on teacher preparation, academic research is today concerned not only with the way pre-service teachers hone their professional tools so that these are "[...] consistent with new understandings of how people learn and what they need to know in the 21st-century knowledge society, which demands workers who can think critically and work collaboratively" (COCHRAN-SMITH, VILLEGAS, 2015, p. 387). Teachers also need to learn how "to teach increasingly diverse student populations" (COCHRAN-SMITH, VILLEGAS, 2015, p. 387). This is what Cochran-Smith and Villegascall the 'learning question' in teacher education current literature. However, those aims and tasks, we claim,

\footnotetext{
${ }^{1}$ University of Greenwich, UK. A.Costantino@gre.ac.uk

${ }^{2}$ Regent's University London, UK. Rollsa@regents.ac.uk
} 


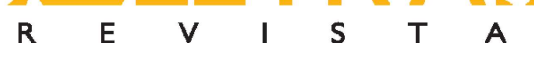

DOSSIÊ-N. 35 - 2018.1 - ANNA COSTANTINO

ASSIA SLIMANI-ROLLS

come with caveats. Teaching and, with it, enacting the notion of good teaching or quality teaching, is increasingly informed by trends and reforms in neoliberal policy and management of educational practices (KEMMIS, 2008, p. xiii), which demand standardised teaching and predictable outcomes, and assume perceptions of homogenised abilities and capabilities in teaching and learning. This leaves little room for teacher reflectivity and risk-taking, namely agency, in times when, paradoxically, teaching is called out to be the deus ex machina of all the problems by which education is ridden.

Furthermore, even when academic research highlights tensions in current neoliberal thinking about education, and accordingly suggests recommendations, often addressing directly and solely policy makers, their findings, again paradoxically, result abstract and far away from teachers' everyday preoccupations and vicissitudes. Most importantly, academic research remains too descriptive for teachers in so far as it does not solve the riddle of what to do in everyday teaching practice, which unfolds contingently across idiosyncratic learning (ALLWRIGHT, HANKS, 2009; HANKS, 2015a; SLIMANI-ROLLS, KIELY, 2014).

Here, we engage in those two paradoxes; one of us as an in-service language teacher and practitioner researcher, one as a leader researcher of a practitioner enquiry project. We collate our reflections that have emerged in both our theoretical and practical work, while experiencing first-hand the tensions facing teaching professionalism in an increasingly bureaucratized working environment. Firstly, we discuss what is at stake in current educational arrangements, against the backdrop of our teaching and research experiences. Then, we engage with some of the critical literature that has advanced suggestions that have relevance to language teacher educators, such as conceptualizations of super-diversity, multiscalarity and third space. Although those critical accounts have foregrounded issues related to teaching "diverse populations of students", they have, nevertheless left unanswered the crucial question of how practitioners can acknowledge diversity in their practice and most importantly, how the spaces of empowerment envisioned in theory can be carved out in practice. We then make connections between conceptualizations on teaching practice and the understandings gained as Exploratory Practice practitioner researchers in a project envisaged as continuous professional development (CPD) for language teachers; a project that has become part of our daily practice as teachers, and researchers. We make a case for implementing practitioner enquiry, as an instance of what we call here unfolding praxis. This is one type of practice that, we claim, is best suited to take up the challenges of the "learning 


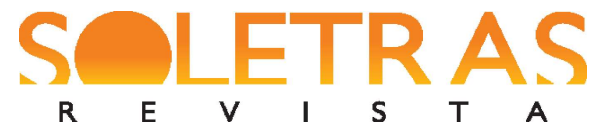

DOSSIÊ-N. 35 - 2018.1 - ANNA COSTANTINO

ASSIA SLIMANI-ROLLS

question", as it provides a fertile ground to confront the challenges that we, language educators, face in increasingly diverse educational settings under ongoing neoliberal reforms. Our reflections also aim at offering an introductory read of practitioner enquiry to those preservice and in-service teachers who will experience or are experiencing a sense of "discomfort" (BALL, OLMEDO, 2013) when called to interrogate and gauge how language teacher professionalism is beheld in current practices and what good teaching should be.

\section{The background of our reflections}

The project that has stimulated some of our reflections was aimed at encouraging language teachers working in UK Higher Education (HE) institutions to become involved in practitioner research and gain a better understanding of the learning dynamics of their context of practice. One of the authors or this paper, became first involved in the project named the Language Teacher Research Project (LTRP), as an MFL teacher at the end of 2014 (see SLIMANI-ROLLS, KIELY, forthcoming).

According to an assessment of the Head of Research prior to the launch of the project, the number of language teaching staff engaged with research was relatively low. Only a small number of staff, mostly linked to the areas of cultural or cross-cultural studies, was research active. The underlying assumptions and rationale of the project was that such an engagement could have the potential to be a powerful transformative force in the work and professional development of language teachers as well as enhance learner experience as a result of understanding. The enquiry was initiated with three MFL (Modern Foreign Language) teachers, as mentioned above, one of us writing this paper, and two EFL (English as Foreign Language) teachers. The lead researcher and co-author of this article, Slimani-Rolls, was also the project mentor.

The project has proved to have gone beyond its intended CPD aims. The involvement of practitioners has protracted up to the time of writing and has facilitated the instantiation of practitioner research as a multifaceted and multilayered stance (COCHRAN-SMITH, LYTLE, 2009): as a professional stance, through self-reflexivity, but also existential and ethical (KEMMIS, SMITH, 2008, p. 7; MILLER, 2010, p. 6), while striving to work towards diversity and inclusion. The next sections aim at sharing our reflectivity work and position theoretically some of our experiences. 


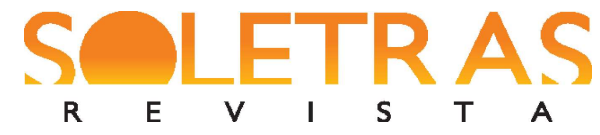

DOSSIÊ-N. 35 - 2018.1 - ANNA COSTANTINO

ASSIA SLIMANI-ROLLS

\section{What is at stake}

As noted above, expectations related to what to learn in a knowledge economy and how to teach diverse student populations raise two paradoxes at least, when viewed from the perspective of the everyday practices of language educators.

Firstly, as also pointed out by Cochran-Smith and Villegas (2015, p. 385), an increase in diversity seems to be paralleled in many countries by an increase in disparities and persistent school/social inequalities' (COCHRAN-SMITH, VILLEGAS, 2015, p. 385), despite the local and national policies implemented to address those problems. This means that the promises of cultural and linguistic enrichment envisaged for society in multilingualism, multiethnicity and multiculturalism are often failed by an overwhelming unequal distribution of educational resources. Furthermore, nurturing diversity, while fostering the attributes that will allow learners to adapt to a world that is in constant economic, social and political change, becomes further complicated by the conditions under which teaching, and learning are managed in contemporary times.

Local educational administrations and authorities are increasingly under pressure to meet national educational standards, which in turn, are informed by and compete with international leagues tables. Examples of this are the surveys known as TIMSS (Trends in International Mathematics and Science Study), PISA (Programme for International Student Assessment) and PIRLS (Progress in International Reading Literacy Study) (Cambridge International Examinations, 2015).

For teachers, educational managers, policy-makers and educational planners adhering to the standards set by nationaland international policies has been put forward and justified by different concerns relating to the state of current global economy and employability and social justice for all.“The learning question' (COCHRAN-SMITH, VILLEGAS, 2015) becomes then intrinsically interwoven with a "policy question" (COCHRAN-SMITH, VILLEGAS, 2015).

This state of affairs has introduced an '[...] unprecedented attention to teacher quality with a heavy emphasis on outcomes accountability (COCHRAN-SMITH, VILLEGAS, 2015, p. 835), which has put in place operational processes of standardisation of educational practise increasingly understood as sets of teaching technologies, and assessment procedures that be best suited to be observed, measured and predicted.Good teaching is thus defined as 'sticking to a script' (RUSSELL, GROOTENBOER, 2008, p. 4) and being subject to "external standards" and agency (GIEVE \& MILLER, 2006, p. 23). Good teaching is about abiding by

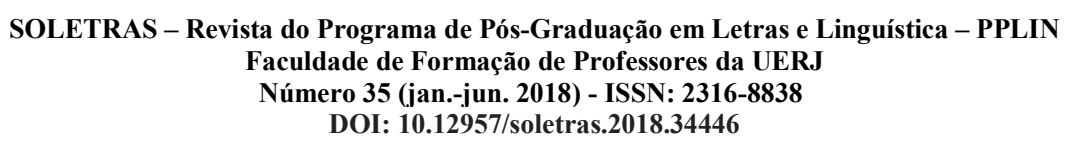




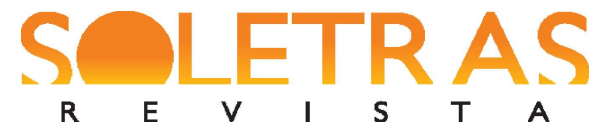

DOSSIÊ-N. 35 - 2018.1 - ANNA COSTANTINO

ASSIA SLIMANI-ROLLS

criteria that are self-regulatory and unrelated to the wealth of multilingual and multicultural resources that educational subjectivities bring to the life of a classroom. By this token, Cochran-Smith and Villegas claim, it is crucial to investigate "the relationships between research practices and social, economic, and institutional power" (COCHRAN-SMITH, VILLEGAS, 2015, p. 391).

However, if we decide to follow this suggestion and seriously question how educators can "[...] navigate the complex tasks of teaching often within school cultures with limited resources and competing expectations" (COCHRAN-SMITH, VILLEGAS, 2015, p. 390), a further paradox arises. We are not only confronted withan issue of professional departmentalization, agency, and power as a state of affairs: teachers teach and apply educational concepts and theory; academics do research and produce knowledge (APPLE, 2005; GIROUX, 1988; ALLWRIGHT, 2013); and educational planners and policy-makers make decision as to what is beneficial socially and politically to a nation or to a wider geopolitical region. Even conceding that academic researchmay somehow orient teachers in finding out ways of reaching out the resources present in everyday classrooms, thus enacting diversity as a value and enrichment for public good, a question remains to be answered as to how and in which conditions teachers can implement the recommendations emerging from the great body of critical literature on educational disparities and inequalities. Teachers keep having to "stick to the script" of management protocols, while their practices become routinized and stultified as "good or best practices". Although there is nothing wrong with routines and techniques, as they constitute part of our daily doings, nevertheless problems arise, we argue, when teaching technologies become internalized to an extent that they become an "order of normative reason", which is both "a behavioural norm" and "a model of subjectivation" (DARDOT \& LAVAL, 2013, p. 3; see also FOUCAULT, 1997); namely when such technologies become internalised by teachers, and learners in a way that such an "order of reason" becomes a rationality that encompasses the full scope of teacher professional identity.

\section{The two paradoxes in globalized and diverse educational settings: inequality of resources and unrelatedness of theory}

Local classroom routines: abiding by the script of managerial models of efficiency and effectiveness and calculability 


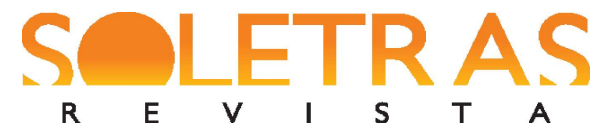

DOSSIÊ-N. 35 - 2018.1 - ANNA COSTANTINO

ASSIA SLIMANI-ROLLS

The shifts in ways of thinking educational arrangements and aims have been for over four decades supported by an ever-growing number of public reforms across western and nonwestern countries (HARVEY, 2005; APPLE, 2005; GIROUX, 2009; ROBERTSON, 2008). Currently dominant understandings of how to administer educational processes and assess the value of education, for instance, understandings as to what is good teaching and good learning - have been modelled upon manufacturing modes of production such as the corporate notion of "total quality management (TQM)", "quality assurance", "client-oriented services", "tailor-made teaching", "achievement-based rewards" (AX, PONTE, 2008, p. 5; KEMMIS, SMITH, 2008); therefore underpinned by neoliberal principles of efficiency, effectiveness and calculability (KEMMIS, SMITHS, 2008; BLOCK, GRAY, HALBOROW, 2013; HALBOROW, 2012).

Educational managerialism has placed a strong emphasis on the market place as the ultimate end of any educational efforts, affecting educational work and relationships in many ways (FITZSIMONS, 2017). It has put forward views of teaching and learning as mandatorily subject to metrics, while making teachers accountable if aims set by local, national and international public policies and authorities, are not met.

Furthermore, facilitated by hard-to-die essentialist and neo-positivistic views of learning, educational managerialism has ushered in perceptions of learning as a commodity. Once measured from modes of behaviour taken at face value, learning not only provides students and educational institutions with reliable metrical values as sound yardsticks to assess quality of teaching and further learning but also with the rationale to sell out the outcomes of any further learning processes. Knowledge and culture, learning and teaching have then been transformed into measurable and quantifiable bits, namely skills, so that they can trade within the knowledge industry (BERNSTEIN et al, 2015, p. 4). This applies to both public and private education. In British and USA schooling, for instance, this translates into league tables of attainment and academic success, which may ultimately decide which schools become the recipient of government funds and which ones will be closed for low attainment (BALL, 2004; BALL, YOUDELL, 2009). The full endorsement and support of league tables by the government has paved the way to academies and free schools in England, or charter schools in the USA, which, although state-funded, allow for private capital investment and involvement to share responsibilities, and interests for public education, which had traditionally been posited in the sole remit of the state. 


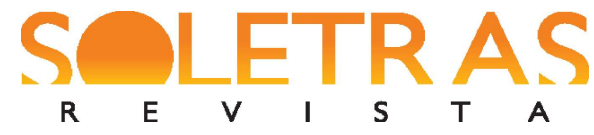

DOSSIÊ-N. 35 - 2018.1 - ANNA COSTANTINO

ASSIA SLIMANI-ROLLS

Global reforms and public policy agenda for equality: Do they work in diverse classrooms?

Concerns over changing conditions in globalized conditions do sit along with national and international preoccupations for economic downturns and inequality. Policy documents from the OECD, the World Bank and other international organizations and governmental bodies increasingly embedded in the national and local policies of the majority of western countries indicate the need to make state management and public services systems more efficient and effective in order to reduce public deficit, which eventually, those directives claim, will allow for levelling social disparities, and increase opportunities to develop financially and economically on an international, national, and local level (OECD, 2013; WORLD BANK, 2015). Analogous patterns of discourse are to be found in policies supporting governmental reforms in the mainstream and tertiary education. They have been similarly justified over the years by the rationale that quality and equity in education is to be sustained efficiently and effectively against the backdrop of financial adversities. Those approaches and trends emphasise that an answer to this is to be looked for in the advantages of market-based and private provisions with regards to quality, equity (WORLD BANK, 1994, p. 4; OECD, 2013) and the efficient and effective containment of financial clap-down in times of financial 'challenges and constraints' (WORLD BANK, 2015) Indeed, it is claimed, the private encourages innovation, accountability, cost effectiveness, social opportunities and mobility (EUROPEAN COMMISSION, 2010, 2016; EUROFOND, 2017) in both developing and developed countries. The private meets consumer demands and expands educational opportunities whereby the state is unable or fails to provide educationally sound opportunities (TOOLEY, 2001; TOOLEY \& DIXON, 2005).

The challenges of poverty in emerging countries is one strong argument that has been hard to challenge in many explanations behind the involvement of the private in educational provisions present in reports and policy papers by transnational organisations (WORLD BANK, 1994, 2015). In fact, as stated in a document issued by the World Bank (2015),

World Bank Group (WBG) research shows that globally, the rates of return for graduates of tertiary education are the highest in the entire educational system-an average 17 percent increase in earnings. Good quality institutions, diversified options, and relevant, equitable and efficient tertiary education and research are key to ending extreme poverty and advancing economic growth (WORLD BANK, 2015, p. 1). 


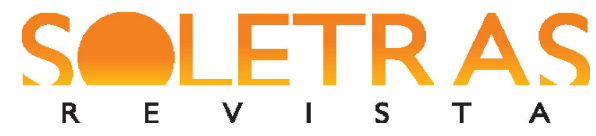

DOSSIÊ-N. 35 - 2018.1 - ANNA COSTANTINO

ASSIA SLIMANI-ROLLS

However, the notion of good teaching as portrayed in policy discourse, however soundly justified in terms of equity and social justice, seems not to be working as it should. In multicultural and multilingual language classroom criteria to measure attainment often clash with forms of diversity, which cannot be measured and therefore often fall outside the criteria set for academic attainment (BALL, BOWE, GEWIRTZ, 1996). This is particularly relevant in poor or deprived areas or in areas with a high number of first generation immigrants (COCHRAN-SMITH, VILLEGAS, 2015, p. 388). In fact, the implementation of educational practices regulated, managed and controlled by managerial model of accountability have been questioned and counteracted by a wealth of literature highlighting the potential enshrined in resources such as multilingual and multicultural diversity and, hence, arguing for educational inclusion.

\section{But how relevant is academic research for everyday educational practices?}

Yet, as Ax and Ponte (2008) note, there is a sense that both managerialism, on the one hand, and educational theory and teaching concepts, on the other hand, are distant and have no relevance to students and learners (AX, PONTE, 2008, p. 5). And there is more at stake in their level of abstraction. As Ax and Ponte (2008, p. 5) argue, managerial models and educational concepts "[...] are not only further away in terms of the degree of abstraction from the daily practice of students and teachers, they are also away from the substance of the educational and moral debate about the kind of education that should be offered to children in our schools and society". Similarly, these considerations apply to the tertiary sector, namely, to learners who are very close to making a difference in society as workers and citizens.

Therefore, we might wonder whether a further question is to be raised as to whether perceptions of teaching that are being gathered together and sold out to the profession as "a combination of technologies of predictions", "client-oriented efficiency" and "manageability" do offer a "coherent", but most importantly, "a desirable image of teaching profession and teachers' professionalism" (AX, PONTE, 2008, p. 5).

Thus, it becomes crucial to interrogate the extent to which critical accounts on diversity and inclusion, which seems to have detected anomalies in current educational practices, are able to translate into diverse and inclusive educational practices that 


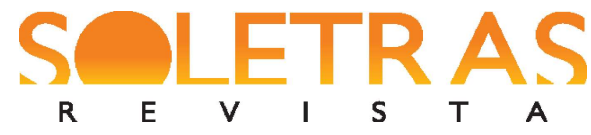

DOSSIÊ-N. 35 - 2018.1 - ANNA COSTANTINO

ASSIA SLIMANI-ROLLS

acknowledge the lived experience of an embodied classroom and its life (GIEVE, MILLER, 2006).

This very tension calls for reflecting upon the nature of the agency that language teachers, together with their learners', can or should exert in response to those challenges. We need to ask which attributes pre-service and in-service teachers need to be endowed with to tap into a diverse classroom. We also need to ask and acknowledge what supports and underpins those qualities and attributes; namely, ask about the nature of the practice in which teaching and learning is implicated and entangled.

The notions of praxis and forms of life, introduced in the next sections, support our argument for interrogating and recovering teacher and learner agency in ways that differ from the "scripts" offered in public policies and managerial strategies and architectures. The notion of praxis that is here featured introduces teachers to a notion of quality of educational practice that differs from that which we have illustrated above. Furthermore, the concept of forms of life grounds it to life, as the world we inhabit, and have in common with other beings.

\section{PRAXIS AND FORMS OF LIFE}

Praxis vs. practice

Kemmis and Smith (2008, p. 263) define praxis as "morally-committed action, oriented and informed by traditions in the field". This notion is connotatively different from the commonly used term practice. This is an important distinction to characterise the qualitative different nature of everyday educational practices. Kemmis and Smith suggest adopting a meaning of praxis that traces back to Greek and Aristotelian usage and linguistic roots $(2008$, p. 4), in that it bypasses the diversity of current everyday meaning of "practice" as "action", "act" or "behaviour" (KEMMIS, SMITH, 2008, p. 4). The term praxis ranges from an understanding of praxis as "social action undertaken in the knowledge that one's actions affect the well-being and interests of others"; to one "[...] that makes transformations in the social world" (see also FREIRE, 1996, [1968]).Thus defined, the term praxis supports an idea of pedagogical action as emancipatory, holistic in its intentionality, aiming at the wellbeing of the participants in any of educational event in which we educators and learners are involved, while keeping political and moral responsibility towards others on a global and local scale in the picture (ALLWRIGHT, 2013). Furthermore, a distinction between praxis and practice helps understand everyday practice as practice constituted of inert practices 


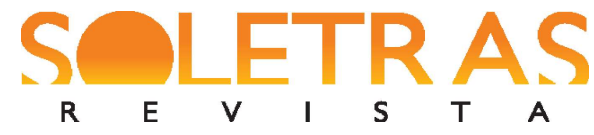

DOSSIÊ-N. 35 - 2018.1 - ANNA COSTANTINO

ASSIA SLIMANI-ROLLS

(JAEGGI, 2013); practices that are taken-for granted, routinized and not reflected upon; but also, it helps think of them as sites nesting relationships that are different from current managerial educational arrangements.

As mentioned early, practitioner enquiry may be envisioned as praxis (KEMMIS, 2010). It can help language educators pierce through inertia by gaining an understanding of their educational work.

\section{Forms of life}

Critical to praxis is the assumption that the educational everyday is a primary dimension in social and educational life. The thinking, feeling and desire, and actions of teachers and learners inhabiting the everyday life are imbued with contingently and historically situated forms of life, which we can interpret as what Kemmis and Smith (KEMMIS, SMITH, 2008, p. 4) view as "tradition". A form of life is a "culturally shaped order of human co-existence"; an "ensemble of practices and orientations as well as their institutional manifestations and materializations" (JAEGGI, 2013, p. 7). Forms of life can be observed in values and beliefs, but also in manifestations such as fashion, architecture, juridical systems and family organization' (JAEGGI, 2013, p. 8), and, therefore, in educational systems. A form of life is directly linked to the 'cultural and social reproduction of human life' (JAEGGI, 2013, p. 7), as it makes it up for its fragility (HABERMAS, 1987).

Forms of life are primarily "inert bundles of social practices" (p. 8). They are "social" since in those "we participate" and "are inaugurated" by. As social and cultural practices, they are activities that are "given" (WITTGENSTEIN, 1958 [1953], p. 226) and precede and presuppose understanding and language (WITTGENSTEIN, 1958 [1953], p. 226). They comprehend routinized practices as well as "implicit knowledge" (WITTGENSTEIN, 1958 [1953], p. 226). Forms of life have amongst their attributes that of being repetitive and habitual while forming the spine of everyday routine. As Jaeggi further argues, they are patterns in which we act. A practice therefore is a set of actions that has a repetitive and a habitual moment and an intrinsic idea of what it means to "fulfil" this practice. They are part of a bundle, since they "encompass a diversity of practices that are related to one another without building an impenetrable and closed totality". Importantly, they are "inert" in the sense that they maintain "sedimentary elements" praxis components that are not always available, explicit, or transparent. Forms of life are not always engaged in deliberately (p. 8- 


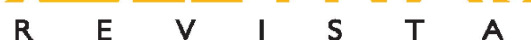

DOSSIÊ-N. 35 - 2018.1 - ANNA COSTANTINO

ASSIA SLIMANI-ROLLS

9). We participate in social practices "without planning, intending, or even knowing, exactly what they are doing", which means that our social relationships function mostly on inherent habitualization, implicit or tacit knowledge.

If a bundle of inert practices is the horizon of our everyday experiences, the challenge for language educational social practices is detecting ways of actualising any "sedimentary elements" of praxis, which involves being connected in inextricable relationships with the world which we inhabit. There are important implications in conceptualizing educational practice as praxis foregrounded in forms of life. All social practices are situated in material, cultural, and discursive conditions of time and space. Those relationships are not always transparent; they are most of the time repetitive, and routinized. Nevertheless, they embed our intentional horizon of meaning and scope for our doings. By such embeddedness and situatedness of practice, teachers cannot eschew the task of being public educators. It is not sufficient to follow 'the script' of public policies. Educators need to become also aware that their acts bear consequences towards other beings and the world which they inhabit. These consequences are both local and global (ALLWRIGHT, 2013).

We need to return to our question as to approach and engage with cultural and linguistic diversity and ask whether a language classroom as formed by a bundle of inert practices, embeds possibilities and spaces for praxis, grounded on forms of life, to unfold.

In the next sessions, we consider ideas developed in critical accounts hitherto, which relate to language education. We first consider conceptualizations that have opened up critical paths for language educators to engage in local and global moral responsibility. While engaging with those conceptualizations, we also seek to respond to their flaws that, we argue, relate to some inability to relate their findings to the everyday classroom.

\section{Global concerns, local opportunities?}

Language learning resources in times of reforms

The reform movements and educational processes aiming at improving quality of teaching and learning have made even more pressing the call for reflecting upon the role that language teachers may play in response to global economic concerns and employability agendas. Increased global flows of capital and commodities, in an ever-interdependent economic world, large-scale migrations movements (VERTOVEC, 2007), along with developments in digital communication and information technologies (BLOMMAERT, 2010;

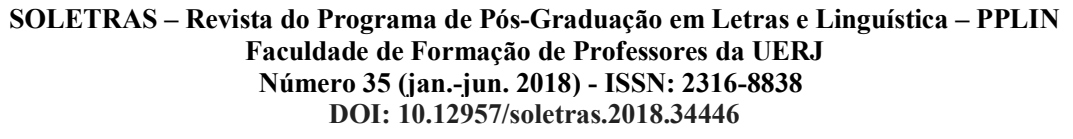




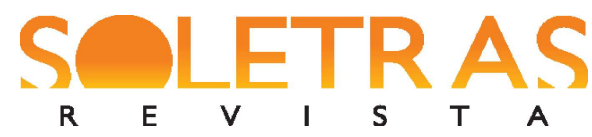

DOSSIÊ-N. 35 - 2018.1 - ANNA COSTANTINO

ASSIA SLIMANI-ROLLS

KRAMSCH, 2014) have reshaped language teacher identities and the perception of what public education is. The latter is being increasingly identified as one of providing tools to adapt to global changes; to prepare learners to be multilingual and cross-culturally competent entrepreneurs while facing challenges and uncertainties. Thus, it is important to consider if, once again, the extent to which such a role is fit for purpose given the current educational arrangements and working conditions for teachers, but also in consideration of the moral and ethical responsibility that we claimed above as being essential for educators.

\section{Critical accounts: valuing local learning resources}

The increasing and relentless processes of reforms have aimed at implementing the "right" measures to make public services such as education efficient and effective so that countries as well as individuals gain a competitive edge against the volatility of markets. However, they have been put under theoretical scrutiny to a great extent. Global changes have not only been engaged with for their challenges but also for the opportunities that they seem to be instantiating or may enact.

Some of the critical responses to the effects of those processes on education have focused on the potential that diversity, encountered in language classrooms as multilingualism and multiculturalism, can bring to educational experiences, indeed as a result of globalization processes. This suggests that diversity as a resource may also be recovered and provide guidelines for "local pedagogies" (CANAGARAJAH, 2002).

Educational resources are understood to be "fluid", "multiscalar" (BLOMMAERT, 2010) and mobile. Perceptions of what constitutes a competent learner and a competent teacher is being shifted and blurred, losing their traditional narrow edges. Allowing for 'inbetween' (BLOMMAERT, RAMPTON, 2012), “contact zones” (PRATT, 1991), those spaces unleashed by globalization mediate between cultures and discourses, permit cross-over of

physically defined and discursive power, and create potential room for acknowledging and valuing difference. Being multiscalar and situated, those practices enjoy attributes such as hybridity (ZEICHNER, 2010; BHABHA, 1996), difference and third space (GUTIERREZ, 2008; GUTIERREZ et al., 1997; COCHRAN-SMITH, LYTLE, 1999). Within those spaces, diversity is indicated as ridden by conflicts and tensions, but also as having critical mass for change. Ethnic diversity is a resource, "an enrichment of society", in that it "[...] gives people opportunities for more varied and challenging experiences, helps people see their own 


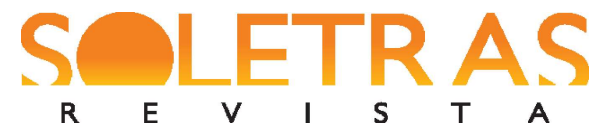

DOSSIÊ-N. 35 - 2018.1 - ANNA COSTANTINO

ASSIA SLIMANI-ROLLS

prejudices, makes 'street life' more varied, leads to exchange of ideas and knowledge, and offers new directions for personal and societal development" (WUBBELS, den BROK, VELDMAN, and van TARTWIJK, 2008, p. 129). Multilingualism is also a resource afforded in language educational practices, since it unfolds across space and time (BLOCK, GRAY, HOLBOROW, 2013, p. 8), through intensified migration movements of workers, students, and refugees, and through developments in global information communication.

Super-diversity and the challenge to standardized and commodified notion of resources

The conceptualisation of super-diversity, coined by Vertovec (2007) in an anthropological context of enquiry, defies traditional ways of looking at ethnicity. Superdiversity not only acknowledges the occurrence of migration flows, but also an increase of number of the categories of immigrant, which make disappear conventional socio-cultural understandings (BLOMMAERT, RAMPTON, 2011, p. 1). Based on the binary categorization of native/immigrant, migration patterns are now to be considered not only in relation to "[...] nationality, ethnicity, language, and religion but also in terms of motives, patterns and itineraries of migration, processes of insertion into the labour and housing markets of the host societies, and so on " (BLOMMAERT, RAMPTON, 2011, p. 1). Learners can tap into native speaker's cultures and environments and learn. Likewise, learners can enrich those very cultures in real time through digital communication.In language education and language literacies classrooms, for instance, this may challenge performative constructions of the good student; one that normally allows for the measuring and the "selling of skills" on the job market. As Ennser-Kananen, Escobar and Bigelow (2017, p.16) argue, the common view in foreign language learning is that language is a commodity which "[...] promotes the idea that [this] is connected to the acquisition of wealth, social status, and professionalism". Engaging with the concept of super-diversity allows also for an acknowledgement of the linguistic richness of immigrant children in their everyday use of multilingual strategies as opposed to mastering a mono-lingual repertoire (GUTIERREZ, 1995, 2008); the latter played discriminatorily against non-dominant student groups.

Understanding events and processes in terms of super-diversity and scales is methodologically useful as "[...] it forces us to think about phenomena, as located in and distributed across different scales, from the global to the local, and to examine the connections between these various levels in ways that do not reduce phenomena and events to 


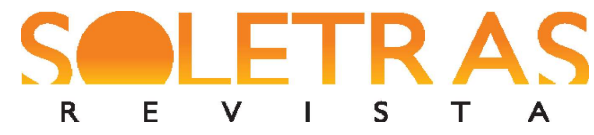

DOSSIÊ-N. 35 - 2018.1 - ANNA COSTANTINO

ASSIA SLIMANI-ROLLS

their strict context of occurrence" (BLOMMAERT, 2010, p. 1). Indeed, layered scales allow an understanding of language as a mobile resource and unfold spaces for maneuvering at "local" (micro) level. These may be unseen or invisible at the global (macro level), nevertheless they are enabling niches of resistance and empowerment.

It is in such spaces that one can begin to think of teaching (and learning) as praxis, as we have argued above: as "morally-committed action, oriented and informed by traditions in the field"; action that embeds a moral and ethical stance.

Canagarajah (1997) has worked on a similar conceptualization arguing for "contact zones" (see also PRATT, 1991). He has illustrated the extent to which the micro lends empowering territory to teaching practice. Canagarajah (2002) alludes to the subversive power of local knowledge: unseen at the higher scale, whether these be institutional or research-based scales, but nevertheless meaningful. As he argues, local knowledge is "context bound, community specific, and nonsystematic because it is generated ground up through social practice in everyday life" (CANAGARAJAH, 2002, p. 244). However, in relation to practitioners, he argues that professionally they "[...] develop a knowledge of accomplishing their work in ways that are not acknowledged or recommended by the authorities/experts. [...] The knowledge generated in our daily contexts of work about effective strategies in language learning and teaching may not enjoy professional or scholarly recognition" (CANAGARAJAH, 2002, p. 243-4). Those considerations reiterated what noted above as an issue of departmentalization of knowledge and power (see also JOHNSON, GOLOMBEK, 2002; ZEICHNER, NOFFKE, 2001)

Although conceptualizations of multilingualism and multiculturalism as a mobile resource are a step forward towards defining teacher preparation in a current globalized society, they still remain problematic. Misdistribution of resources, Blommaert (2010, p. 5) argues, is as a matter of "access and control over scales" which is "unevenly distributed" and this is clear "[...] when we consider typical resources for access to higher (i.e. non-local and non-situationally specific) scales such as a sophisticated standard language variety or advanced multimodal literacy skills" (BLOMMAERT, 2010, p. 5).

This is an important point since it grasps the crucial considerations highlighted earlier relating to the extent to which language educators and learners can "access and control" those resources while sticking to the script. Canagarajah (2002) has touched upon the existence of 


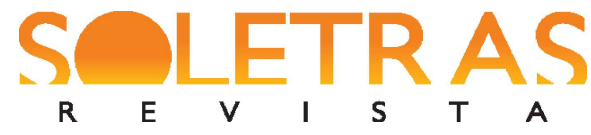

DOSSIÊ-N. 35 - 2018.1 - ANNA COSTANTINO

ASSIA SLIMANI-ROLLS

teacher knowledge as unlikely to be acknowledged in higher scales of power, and, nevertheless, is what works in classrooms.

Yet it is not enough to acknowledge the existence of local knowledge as embraced by teachers and located in hidden and often invisible spatial scales. At stake is to be able to detect as to how pedagogical practices can bypass the power hierarchy inherent in those scales and the awareness of it so that maldistributed resources might converge into the here-and-now of a classroom.

\section{Bridging the gap between descriptive theory and lived classroom experience}

Thus, the critical accounts that we have considered hitherto are welcomed, in that they provide researchers as well as educators with a theoretical window that allows to value and appreciate linguistic and cultural diversity. Furthermore, they provide us with strong visual imaginary - the multiscalarity, for instance -that helps envisage sites in our remit of practice wherein teachers and their preparation - their knowledge, abilities and attributes - may cross scales and access learning resources.

However, as noted above, they are insufficient to answer questions that arise in 'situated' language classrooms. And it is not solely because those spaces are theorized by academics, and therefore, may remain abstract to the majority of teachers. An awareness of their existence that remains confined at a level of discursive mediations alone, would never be able to render experientially the idiosyncratic and often fragile ecosystem of a lived language classrooms. Here, the existentially and bodily situated classroom with idiosyncratic paces of learning, experiences and desires become stretched through and constrained by the unidirectional relationships scripted and contracted by the educational institutions and policy. For instance, it would be difficult for language educators to work out the extent to which mechanisms of linguistic and cultural mediations, permitted by a globalized society, and widely descripted in theoretical and empirical research, can be translated into'access and control over scales' in unevenly distributed learning resources.Inclusive pedagogical practices would need to break in the walls of the inert everyday of language classrooms, which are mainly constituted of classroom objectives, technologies and architectures of learning and teaching routines, all of which are managerially parcelled out so that they can be observed and measured. The teaching and learning "predispositions" (KEMMIS, SMITH, 2008), which 


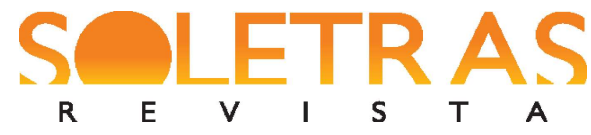

DOSSIÊ-N. 35 - 2018.1 - ANNA COSTANTINO

ASSIA SLIMANI-ROLLS

feed on and foster a sense of responsibility towards the world we inhabit become inevitably overshadowed (AX, PONTE, 2018).

\section{Tapping into educational everyday life resources}

Practitioner enquiry as multiscalar resource for praxis: trespassing the managerial script

Some of the considerations developed above have fed, but also stemmed, from our ongoing work as EP practitioner researchers and language teachers. In the remaining sections, we connect the discussions in which we have engaged hitherto to some of the features and understandings which have emerged in our practitioner enquiry practice, highlighting what, we argue, are the facets that may have allowed us to approach and enact multiscalarity as lived experience.

As mentioned above, the enquiry with which we both have been engaged for nearly four years was initiated as a CPD instance. However, while the project seemed to be aiming at implementing managerial and policy agendas related to research activity amongst staff, on the other hand, in its inception, it appeared to be instrumental to question 'the taken-for-granted' of everyday teaching and learning through honing awareness and understanding of both teachers and learners' doings.

This lends itself to be interpreted as a way of trespassing the hierarchy of scales or even a way of enacting a space that can be thought as an empowering "third space" (ZEICHNER, 2010; GUTIÉRREZ, 2008; GUTIERREZ, BAQUEDANO-LOPEZ, TURNER, 1997; SOJA, 1998; FORGASZ et al., 2018). Third spaces, Zeichner (2010, p. 92) argues, "[...] involve a rejection of binaries such a practitioner and academic knowledge and theory and practice and involve the integration of what are often seen as competing discourses in new ways -as either/or perspective is transformed into a both/also point of view".

The space opened by managerial decisions also lends itself to be read in a "multiscalar" perspective in a sense that diversity of resources and scales may be viewed not as abstract conceptualizations, detached from everyday teaching practice, but indeed as praxis, in part initiated by those very levels that we have claimed as inhibiting self-reflectivity and, as very often it is the case, risk-taking, once and if teachers do not follow the script.

A language classroom as a sustainable form of life: acknowledging concreteness and materiality of life 


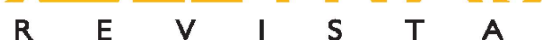

DOSSIÊ-N. 35 - 2018.1 - ANNA COSTANTINO

ASSIA SLIMANI-ROLLS

However, it was the work of all the co-researchers involved - the language teachers, the learners and the mentor of the practitioner enquiry - their vicissitudes and, we argue, the overwhelming burden of forms of life piercing through the inertia of standardized practices that made the space of our enquiry a lived and visible experience, otherwise hidden.

As mentioned in our Introduction, our practitioner enquiry has been methodologically framed by EP, a form of practitioner research successfully implemented in recent years across the world mostly in language education.

The decision of undertaking professional development through EP was based upon the nature of our diverse personal interests in $\mathrm{CPD}$, but also working conditions. We became soon aware that the thrust towards working sustainably, one of the principles of Exploratory Practice, was a major drive for us, the participant practitioner researchers, since the enquiry could fit our busy and overload routine (COSTANTINO, 2018). In order to enable sustainability throughout the enquiry, EP encourages both learners and teachers "to investigate their own learning/teaching practices while concurrently practising the target language" (HANKS, 2017, p.2). We, from the beginning, have been using a variety of classroom activities as investigative tools such as classroom conversation, questionnaires, pair-/group-work, reading and listening comprehension tasks, picture stories and creative writing, so that the inquiry sustainably has fallen within classroom routines and work has not been further burdened. Interestingly, as it became apparent after a first phase when we collated our reflections in individual case studies (SLIMANI-ROLLS, KIELY, forthcoming), this approach to classroom activities proved to have significantly shifted the balance between the educational powers at play. In an almost unnoticed mode for us at the beginning, our practice moved from being top-down to being bottom-up generated. We began to be in charge of resources such as our language techniques and materials for the sake of and in the interests of the classroom participants rather than for a self-regulatory managerial educational protocol. Our teaching common sense, result of inert and routinized practices and perceptions, have begun to be exercised through judgment about our learners as contingently situated in the unfolding of our ever-diverse classroom dynamics.

A language classroom as an inclusive form of life: acknowledging connectedness to other human beings 


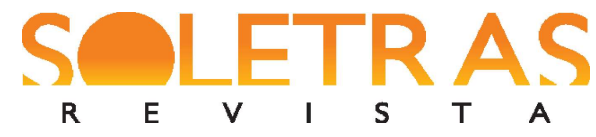

DOSSIÊ-N. 35 - 2018.1 - ANNA COSTANTINO

ASSIA SLIMANI-ROLLS

As a language teacher, one of the authors approached EP because she was also interested in forms of pedagogy that could enact inclusivity (COSTANTINO, 2018). EP seemed to emphasize inclusivity in many ways. EP appreciates inclusivity (ALLWRIGHT, 2003; ALLWRIGHT, HANKS, 2009) in that it seeks to integrate research and pedagogy. Integrating pedagogy and research 'for and by learners and teachers' (HANKS, 2015, p. 117) is a major proposition of EP. However, EP does not seem to be only about blurring the boundaries of professional remits such as that between the teacher and the researcher. It also predicates on "bringing the different stakeholders (learners, researchers, and teachers) together as they set their own, personally and professionally relevant, research agendas [...]" (HANKS, 2017, p. 38). As Hanks points out, "the aim is to work for mutual development, [...] what helps the researcher also helps the teacher, and, at the same time, the learners understand more about language learning/teaching" (HANKS, 2017, p. 39). It is in this sense that in our enquiry we have seen instantiating the openings envisaged by what has been theorized with super-diversity, third-space and multiscalarity literature; as an embodiment of connectedness amongst the co-participants as belonging to a common unfolding form of life and tradition.

A language classroom as an empowered form of life: acknowledging agency and life through puzzling

Perhaps the most powerful tool to achieve this realization is through puzzling. An Exploratory Practice enquiry begins with a puzzle phrased as a 'why' question which is posited by both teachers and learners. The puzzles that our enquiry generated (see SLIMANIROLLS, KIELY, forthcoming) were for instance: Why don't the students make the most of the written feedback? (COSTANTINO, forthcoming) Why do students use the mother tongue during the class? (RAWSON, forthcoming)Why do I feel I need to improve my skills for teaching speaking? (HOUGHTON, forthcoming) Why do students use their mobiles during the class? (LUCUMBERRI, forthcoming) Why do I feel that I do not obtain from students sufficient high quality usable feedback and evaluation of course content and methodology? (BANISTER, forthcoming) Why do students' presentations and discussion board work so well? (GORAL, forthcoming)

Puzzles might look perhaps trivial to conventional academic research, as they do not aim at producing knowledge and generalisations as research questions are expected to. On the 


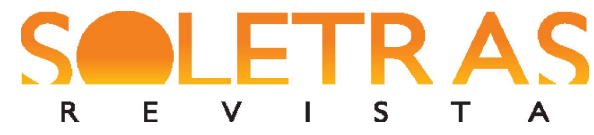

DOSSIÊ-N. 35 - 2018.1 - ANNA COSTANTINO

ASSIA SLIMANI-ROLLS

contrary, they are powerful tool for understanding, as they go against the grain of the managerial protocols of learning and teaching. They enable ideas of competence other than one which is entrenched in the common-sense notion of good teacher and good learner. We like to think of our puzzles as humble insurgences. Indeed, puzzles and puzzlement witness the insurgence of tensions between the scripts that teachers are supposed to follow, and the daily vicissitudes of learners' and practitioners; between common sense and a sense of 'discomfort' (BALL, OLMEDO, 2013) that pounds through inert and routinized practices, no matter how. Those tensions as they emerge in the everyday classroom should be dismissed in any account on language teacher professionalism.

\section{References}

ALLWRIGHT, D. Exploratory Practice: Rethinking practitioner research in language teaching. Language Teaching Research, 7(2), 2003, p. 113-141.

.Theorizing "Down" Instead of "Up": The Special Contribution of Exploratory Practice. KOTESOL Proceedings, 2013.

; HANKS, J. The Developing Language Learner: An introduction to Exploratory Practice. Basingstoke: Palgrave Macmillan, 2009.

APPLE, M. W. Education, markets, and an audit culture. Critical Quarterly, 47, 2005, p. 1129.

AX, J.; PONTE, P. Praxis: Analysis of theory and practice. Critiquing praxis, 1-20. In: AX, J., \& PONTE, P. (Eds.). Critiquing praxis: Conceptual and empirical trends in the teaching profession. Pedagogy, education and praxis, (2). Rotterdam, The Netherlands: Sense, 2008.

BALL, S. Education for sale! The commodification of everything? King's Annual Education Lecture 2004, University of London, Institute of Education, June 17, 2004.

; OLMEDO, A. Care of the self, resistance and subjectivity under neoliberal governmentalities. Critical Studies in Education, 54(1), 2013.85-96. Retrieved from: http://old.ei-ie.org/annualreport2007/upload/content trsl images/440/Hidden privatisationEN.pdf 2009.

;YOUDELL, D. Hidden privatisation in public education. Education Review, 21(2),

; BOWE, R.; GEWIRTZ, S. School choice, social class and distinction: the realization of social advantage in education. Journal of education policy, 11(1), 1996, p. 89-112. 


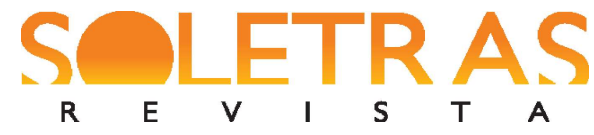

DOSSIÊ-N. 35 - 2018.1 - ANNA COSTANTINO

ASSIA SLIMANI-ROLLS

BANISTER, C. Rebuilding practitioner self-efficacy through learner feedback In: SLIMANIROLLS, A.; KIELY. R. (forthcoming). Exploratory Practice for Continuing Professional Development: An Innovative Approach for Language Teachers. Palgrave Macmillan, (forthcoming).

BERNSTEIN, K. A.; HELlMiCH, E. A.; KATZNELSON, N.; SHIN, J.; VINALL, K. Introduction to special Issue: Critical perspectives on neoliberalism in second/foreign language education. L2 Journal, 7(3), 2015.

BHABHA, H. K. The location of culture. New York, NY: Routledge, 1994.

BLOCK, D.; GRAY, J.; HOLBOROW, M. Neoliberalism and applied linguistics. New York, NY: Routledge, 2013.

BLOMMAERT, J. The sociolinguistics of globalization. Cambridge: Cambridge University Press, 2010.

; RAMPTON, B. Language and Superdiversity. Diversities, 13(2), 2011, p.1-21.

CAMBRIDGE INTERNATIONAL EXAMINATIONS INTERNATIONAL SURVEYS: PISA, TIMSS, PIRLS. Education Brief 7, 2015. Retrieved:

http://www.cambridgeinternational.org/images/271193-international-surveys-pisa-timsspirls.pdf

CANAGARAJAH, S. Safe houses in the contact zone: Coping strategies of African-American students in the academy. College Composition and Communication, 48(2), 1997, p.173-196.

CANAGARAJAH, S. Reconstructing local knowledge. Journal of Language, Identity, and Education, 1(4), 2002, p. 243-259.

COCHRAN-SMITH, M.; LYTLE, S. L. The teacher research movement: A decade later. Educational researcher, 28(7), 1999, p.15-25.

COCHRAN-SMITH, M.; LYTLE, S. L. Inquiry as stance: Practitioner research for the next generation. New York: Teachers College Press, 2009.

COCHRAN-SMITH, M.; VILLEGAS, A. M. Studying teacher preparation: The questions that drive research. European Educational Research Journal, 14(5), 2015, p. 379-394.

COSTANTINO, A. Understanding 'Local' Pedagogy: a written feedback puzzle. In: SLIMANI-ROLLS, A.; KIELY, R. Exploratory Practice for Continuing Professional Development: An Innovative Approach for Language Teachers. Palgrave Macmillan, (forthcoming).

DARDOT, P.; LAVAL, C. The new way of the world: On neoliberal society. London, New York:Verso Books, 2014. 


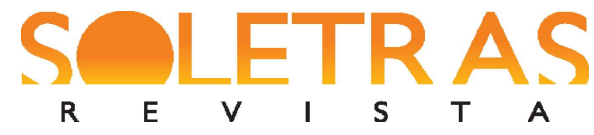

DOSSIÊ-N. 35 - 2018.1 - ANNA COSTANTINO

ASSIA SLIMANI-ROLLS

ENNSER-KANANEN, J.; ESCOBAR, C. F.; BIGELOW, M. "It's Practically a Must": Neoliberal Reasons for Foreign Language Learning. International Journal of Society, Culture \& Language, 5(1), 2017, p. 15-28.

EUROFOUND. Social mobility in the EU. Publications Office of the European Union, Luxembourg, 2017. Retrieved from: < https://www.eurofound.europa.eu/sites/ default/files/ ef_publication/field_ef_document/ef1664en.pdf $>$

EUROPEAN COMMISSION. Social mobility and intraregional income distribution across EU Member States. DG Regional Policy, Brussels. 2010. Retrieved from: $<$ http://ec.europa.eu/regional_policy/sources/docgener/studies/pdf/sm_es_08072010_en.pdf>

.Smart Smarter, greener, more inclusive? Indicators to support the Europe 2020.Luxembourg: Office for Official Publications of the European Communities.2016. Retrieved from: <http://ec.europa.eu/eurostat/documents/3217494/7566774/KS-EZ-16-001EN-N.pdf/ac04885c-cfff-4f9c-9f30-c9337ba929aa>.

FITZSIMONS, P. Managerialism and Education, 1-5. In: PETERS, M.; GHIRALDELLI, P., ŽARNIĆ, B.; GIBBONS, A.; BESLEY, T. (eds.).The Encyclopaedia of Educational Philosophy and Theory, 2017. Retrieved from: <http://eepat.net/doku.php?id=managerialism and_education>.

FORGASZ, R.; HECK, D.; WILLIAMS, J.; AMBROSETTI, A.; WILLIS, L. D. Theorising the Third Space of Professional Experience Partnerships. In: Educating Future Teachers: Innovative Perspectives in Professional Experience. Springer, Singapore, 2018, p. 33-47.

FOUCAULT, M. The Ethics of the Concern of the Self as a practice of Freedom. In: RABINOW, Paul (ed.) Ethics: Subjectivity and Truth. Essential Works of Michel Foucault.1954-1984, Vol.1. New York: New Press, 1997.

FREIRE, P. Pedagogy of the oppressed. London: Penguin Books, [1968]1996.

GIEVE, S.; MILLER, I. K. (eds.). Understanding the Language Classroom. Basingstoke: Palgrave Macmillan, 2006.

GIROUX, H. A. Teachers as intellectuals: Toward a critical pedagogy of learning. Greenwood Publishing Group, 1988.

Critical Theory and Educational Practice. In: DARDER, A.; BALTODANO, M.P.; TORRES, R.D. (eds.).The Critical Pedagogy Reader. New York: Routledge, 2009, p. 27-51.

GORAL, M. Exploratory Practice: Embracing new identities. In: SLIMANI-ROLLS, A.; KIELY, R. Exploratory Practice for Continuing Professional Development: An Innovative Approach for Language Teachers. Palgrave Macmillan, (forthcoming).

GUTIÉRREZ, K. D. Developing a sociocritical literacy in the third space. Reading research quarterly, 43(2), 2008, p.148-164. 


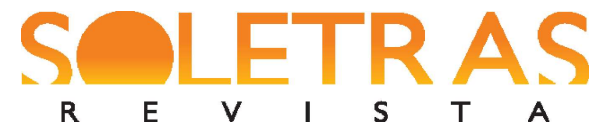

DOSSIÊ-N. 35 - 2018.1 - ANNA COSTANTINO

ASSIA SLIMANI-ROLLS

BAQUEDANO-LOPEZ, P.; TURNER, M. G. Putting Language Back into Language Arts: When the Radical Middle Meets the Third Space. Language Arts, 74(5), 1997, p. 36878.

HABERMAS, J. The Theory of Communicative Action, Volume 2. Lifeworld and System: A Critique of Functionalist Reason. Cambridge: Polity Press, 1987.

HANKS, J. 'Education is not just teaching': learner thoughts on Exploratory Practice. ELT Journal: English Language Teaching Journal, 69(2), 2015, p.117-128.

Integrating research and pedagogy: An Exploratory Practice approach. System, 68, 2017, p. 38-49.

Harvey, D. A brief history of neoliberalism. Oxford: Oxford University Press, 2005.

HOLBOROW, M. Neoliberal keywords and the contradictions of an ideology. Neoliberalism and applied linguistics, 2012, p.33-55.

HOUGHTON, J. Gaining deeper understanding of teaching and learning from collaborative inquiry. In: SLIMANI-ROLLS, A.; KIELY, R. Exploratory Practice for Continuing Professional Development: An Innovative Approach for Language Teachers. Palgrave Macmillan,(forthcoming).

JAEGGI, R. Critique of Forms of Life Forms of Life as Instances of Problem-solving. Porto Alegre, Sept. 2013. Retrieved from: <http://cef.pucp.edu.pe/wp- Rahel-Jaeggi-Critique-ofcontent/uploads/2014/08/Forms-of-Life-Brasil-2013.pdf>

JOHNSON, K. E.; GOLOMBEK, P. R. (eds.).Teachers' Narrative Inquiry as Professional Development. Cambridge: Cambridge University Press, 2002.

KEMMIS, S. Foreword, xi-xvii. In: AX, J.; PONTE, P. (eds.). Critiquing praxis: Conceptual and empirical trends in the teaching profession. Pedagogy, education and praxis, (2). Rotterdam, The Netherlands: Sense, 2008.

27.

Research for praxis: Knowing doing. Pedagogy, Culture \& Society, 18(1), 2010, p. 9-

; SMITH, T. Praxis and praxis development (3-13). In ; SMITH, T. (eds.). Enabling praxis: Challenges for education. Rotterdam, The Netherlands: Sense, 2008.

KRAMSCH, C. Teaching foreign languages in an era of globalization: Introduction. The modern language journal, 98(1), 2014, p. 296-311.

LUCUMBERRI, E. Mobile phones in my language classroom: a cause for concern or a source of communication? In: SLIMANI-ROLLS, A.; KIELY, R. Exploratory Practice for 


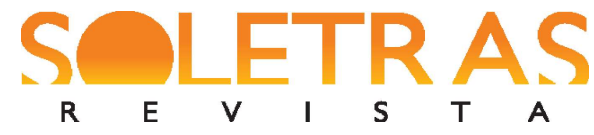

DOSSIÊ-N. 35 - 2018.1 - ANNA COSTANTINO

ASSIA SLIMANI-ROLLS

Continuing Professional Development: An Innovative Approach for Language Teachers. Palgrave Macmillan, (forthcoming).

MILLER, I. K. Exploratory Practice: Towards Inclusive and Reflexive Teacher Education. Tercer Foro de Lenguas de ANEP. Montevideo: 2010. Tercer Foro De Lenguas De ANEP. Retrieved from: $<$ http://Doscubos.Com/Clientes/3Fla/Ponencias/023.Pdf. $>$

OECD What is the impact of the economic crisis on public education spending? Education Indicators in Focus. Washington, DC: World Bank. 2013. Retrieved from: http://www.oecd.org/edu/skills-beyond-school/EDIF\%202013--N\%C2\%B018\%20(eng).pdf

PRATT, M. L. Arts of the contact zone. Profession, vol. 91, 1991, p. 33-40.

RAWSON, M. Using the mother tongue in the language classroom: hindrance or help?In: SLIMANI-ROLLS, A.; KIELY, R. Exploratory Practice for Continuing Professional Development: An Innovative Approach for Language Teachers. Palgrave Macmillan, (forthcoming).

ROBERTSON, S. L. "Remaking the World" Neoliberalism and the Transformation of Education and Teachers' Labor. In: The Global Assault on Teaching, Teachers, and their Unions Stories for Resistance. Palgrave Macmillan US, 2008. Retrieved from: $<$ http://www.bris.ac.uk/education/people/academicStaff/edslr/publications/17slr>

RUSSELL, H.; GROOTENBOER, P. Finding praxis. Enabling praxis: Challenges for education. In: KEMMIS, S.; SMITH, T. (eds.). Enabling praxis. Rotterdam, The Netherlands: Sense, 2008, p. 109-126.

SLIMANI-ROLLS, A.; KIELY, R. Exploratory Practice for Continuing Professional Development: An Innovative Approach for Language Teachers. Palgrave Macmillan, (forthcoming).

SLIMANI-ROLLS, A. Exploring a world of paradoxes: an investigation of group work. Language Teaching Research, 7(2), 2003, p. 221-239.

SLIMANI-ROLLS, A.; KIELY, R. 'We are the change that we seek': developing teachers' understanding of their classroom practice. Innovations in Education and Teaching International, 51(4), 2014, p. 425-435.

SOJA, E. W. Thirdspace: Journeys to Los Angeles and other real-and-imagined places. Capital \& Class, 22(1), 1998, p. 137-139.

The World Bank Higher Education: The Lessons of Experience. Washington, DC: World Bank, 1994. Retrieved from: <http://siteresources.worldbank.org/EDUCATION/Resources/ 278200-1099079877269/547664-1099079956815/HigherEd_lessons_En.pdf> 


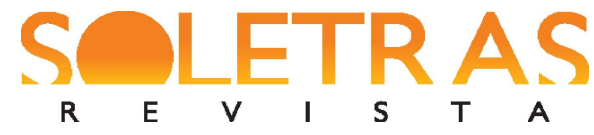

DOSSIÊ-N. 35 - 2018.1 - ANNA COSTANTINO

ASSIA SLIMANI-ROLLS

The World Bank Education Global Practice: Smarter Education Systems for Brighter Futures. Washington, DC: World Bank, 2015. Retrieved from: $<$ http://documents.worldbank.org/ curated/en/613701468188661472/pdf/98454-REVISED-Box393212B-PUBLIC.pdf>

TOOLEY, J. Serving the needs of the poor: The private education sector in developing countries. In: HEPBURN, C. R (ed.). Can the Market Save Our Schools? The Fraser Institute, 2001.

TOOLEY, J.; DIXON, P. Private education is good for the poor: A study of private schools serving the poor in low-income countries. Washington, DC: Cato Institute, (2005). Retrieved from: $\quad<$ http://www.cato.org/publications/white-paper/private-education-is-good-poor-studyprivate-schools-serving-poor-lowincome-countries $>$

VERTOVEC, S. Super-diversity and its implications. Ethnic and racial studies, 30(6), 2007, p.1024-1054.

WITTGENSTEIN, L. Philosophical investigations. Oxford: Wiley-Blackwell, (1958 [1953]). $<$ https://static1.squarespace.com/static/54889e73e4b0a2c1f9891289/t/564b61a4e4b04eca59c4 d232/1447780772744/Ludwig.Wittgenstein.-.Philosophical.Investigations.pdf>

ZEICHNER, K. Rethinking the connections between campus courses and field experiences in college-and university-based teacher education. Journal of teacher education, 61(1-2), (2010), p. 89-99.

; NOFFKE, S. E. Practitioner Research. In: RICHARDSON, V. (ed.), Handbook of Research on Teaching, $4^{\text {th }}$ ed., Washington: American Educational Research Association, 2001, p. 298-330.

\section{A pesquisa do praticante e os desafios do cânone do bom ensino em uma sociedade multilíngue, multicultural e globalizada}

Resumo: O presente artigo busca responder a algumas das tensões que se colocam para os formadores de professores de línguas em uma sociedade globalizada. Para os professores, um mundo globalizado cada vez mais multicultural, multilíngue e marcado pela diversidade significa ter que reconhecer a diversidade em sua prática docente cotidiana, ao mesmo tempo tendo que enfrentar a desigualdade na distribuição de recursos de aprendizagem bem como as demandas de contextos educacionais burocratizados. Mesmo quando a teoria indica espaços para a criação de pedagogias locais que respondam a tais desafios, os professores não conseguem traduzir a pesquisa acadêmica em prática. Esse artigo traz argumentos em favor da pesquisa do praticante, praticada pelas autoras de acordo com a Prática Exploratória (ALLWRIGHT, HANKS, 2009; HANKS, 2015a; SLIMANI-ROLLS, KIELY, 2014), enquanto um caminho para fazer com que os espaços de empoderamento sugeridos pela teoria possam realmente ser construídos como experiência educacional vivida.

Palavras-chave: Prática Exploratória, formação de professores de línguas, pesquisa do praticante, globalização. 
R E V I S T A

DOSSIÊ-N. 35 - 2018.1 - ANNA COSTANTINO

ASSIA SLIMANI-ROLLS

Recebido em: 14 de abril de 2018.

Aprovado em: 20 de maio de 2018.

Número 35 (jan.-jun. 2018) - ISSN: 2316-8838 